\title{
KHẢO SÁT ĐẶC ĐIỂM CỦA SIÊU ÂM TRONG VIÊM PHổI CÓ BIẾN CHỨNG Ở TRẺ EM
}

\section{TÓM TẮT}

Mục tiêu: Khảo sát một số đặc điểm của siêu âm ở bệnh nhi bị viêm phổi có biến chứng. Đối tượng, phương pháp: Dân số chọn mẫu là những đối tượng bênh nhân ở trên được chẩn đoán viêm phổi tại khoa Hồ hấp và các khoa khác tại Bệnh viện Nhi đồng I Thành phố Hồ Chí Minh từ tháng 9/2018 đến tháng 7/2019. Phương pháp nghiên cứu: nghiên cứu hồi cứu kết hợp tiến cứu (mô tả ca bênh). Nghiên cứu mô tả đặc điểm siêu âm phổi ở bệnh nhi viêm phổi có biến chứng với $X$-quang cắt lớp vi tính là tiêu chuẩn vàng chẩn đoán. Kết quả: Các dấu hiệu tổn thương viêm phổi cơ bản thường găp theo thứ tự là dấu hiệu đông đặc, mất dấu hiệu trượt màng phổi và đường $B$ với tỷ lế lấn lướt là $94,3 \%, 28,6 \%$ và $20,0 \%$. Các dấu hiêuu tổn thương của biến chứng viêm phổi hay gặp theo thứ tư là dấu hiếu quad, dấu hiệu signoid và dẩu hiệu lung point với tỷ lệ lần lượt là $53,4 \%, 25,7 \%$ và $14,3 \%$. Xẹp phổi, tràn dịch màng phối, viêm phổi hoại tử và tràn khí màng phổi là các biến chứng hay gặp của viêm phổi, với tỷ lệ tương ứng là $62,9 \%, 57,1 \%$, $40 \%$ và 14,3\%. Kết luận: Siêu âm phổi là phương tiện chẩn đoán hình ảnh không xâm lấn có giá trị kinh tể cao so với các phương tiện chẩn đoán hình ảnh khác như chụp X-quang cắt lớp vi tính ngực, Chụp cộng hưởng từ...

Tư khoá: Siêu âm, viêm phổi, biến chứng

\section{SUMMARY \\ CHARACTERISTICS OF LUNG ULTRASOUND IN DIAGNOSIS OF COMPLICATED PNEUMONIA IN CHILDREN}

Objective: To investigate some features of ultrasound in pediatric patients with complicated pneumonia. Subjects and methods: The pediatric patients who were diagnosed with pneumonia at the Respiratory Department and other departments at Children's Hospital I - Ho Chi Minh City from September 2018 to September 2018. 7/2019. Methods: Retrospective combined prospective study (case description). Study on characteristics of lung ultrasound in pediatric patients with complicated pneumonia with CT scan as the diagnostic gold standard. Results: The common signs of basic pneumonia were, in order, signs of consolidation, loss of signs of pleural slip and line $B$ with the rates of $94.3 \%, 28.6 \%$ and $20,0 \%$ respectively. The common signs of pneumonia complications are, in order, the quad sign, signoid sign and lung point sign with the

*Trường Đại học Y Phạm Ngọc Thạch, Tp Hồ Chí Minh Chịu trách nhiệm chính: Ngô Minh Xuân

Email: xuanlien62@pnt.edu.vn

Ngày nhận bài: 4.3.2021

Ngày phản biện khoa học: 26.4.2021

Ngày duyệt bài: 10.5.2021
Ngô Minh Xuân*

rate of $53.4 \%, 25.7 \%$ and $14.3 \%$, respectively. Atelectasis, pleural effusion, necrotizing pneumonia, and pneumothorax are common complications of pneumonia, with rates of $62.9 \%, 57.1 \%, 40 \%$ and $14.3 \%$, respectively. Conclusion: Lung ultrasound is a non-invasive imaging tool with high economic value compared to other imaging methods such as chest computed tomography, Magnetic resonance imaging...

Keywords: Ultrasound, pneumonia, complications

\section{I. ĐĂT VẤN ĐỀ}

Viêm phổi là một bệnh phổ biến trên thế giới và là nguyên nhân gây tử vong hàng đầu ở trẻ dưới 5 tuổi. Hàng năm có khoảng 156 triệu trường hợp mắc mới, trong đó chủ yếu ở các nước đang phát triển, số lượng bệnh nhi tử vong do viêm phổi là 1,9 triệu trường hợp [4].

Việc chẩn đoán viêm phổi ở trẻ em, cũng như biến chứng của viêm phổi có vai trò đặc biệt quan trọng trong điều trị và tiên lượng bệnh. Hiện nay, chẩn đoán viêm phổi và biến chứng của viêm phổi chủ yếu dựa vào bệnh sử, triệu chứng lâm sàng như sốt, ho, nhịp thở nhanh, khó thở, khò khè... Khi trẻ được nghi ngờ viêm phổi thì X-quang ngực vẫn là phương tiện chẩn đoán hình ảnh đầu tiên được lựa chọn để chẩn đoán. X-quang cắt lớp vi tính ngực là phương tiên phát hiện tổn thương thâm nhiễm tốt hơn so với $X$-quang ngực. Tuy nhiên việc chụp $X$-quang cắt lớp vi tính ngực thường quy (khi cân) gặp nhiều khó khăn do làm tăng chi phí điều trị, tăng phơi nhiễm với tia phóng xạ và đặc biệt là không thể thực hiện tại giường cho nhửng bệnh nhi bi viêm phổi nặng [1].

Những hạn chế của $X$-quang và $X$-quang cắt lớp vi tính ngực nêu trên đã thúc đẩy việc tìm ra một kĩ thuật mới để chẩn đoán viêm phổi ở trẻ em. Trong những năm gần đây, có nhiêu tác giả đã nghiên cứu đánh giá vai trò của siêu âm trong chẩn đoán viêm phổi cũng như biến chứng của viêm phổi và thu được những kết quả khả quan nhất định. Khả năng chẩn đoán của siêu âm trong các nghiên cứu trên đạt tới độ nhạy $95 \%-97 \%$, độ đặc hiệu $90 \%-94 \%$. Cùng với đó siêu âm phổi có thể thực hiện tại giường, làm lại nhiều lần, cho kết quả ngay và không bị phơi nhiễm với tia phóng xạ. Một số nghiên cứu cho thây siêu âm có giá trị tương đương với X-quang cắt lớp vi tính lồng ngực và có thể là phương tiện thay thế $X$-quang ngực trong chẩn đoán viêm phổi [5]. 
Vì vậy chúng tôi tiến hành nghiên cứu đề tài này nhằm Khảo sát một số đặc điểm của siêu âm ở bệnh nhi bị viêm phổi có biến chứng.

\section{II. ĐỐI TƯỢNG VÀ PHƯƠNG PHÁP NGHIÊN CỨU}

2.1. Đối tượng nghiên cứu. Dân số chọn mẫu là những đối tượng bệnh nhân ở trên được chẩn đoán viêm phổi tại khoa Hô hấp và các khoa khác tại Bệnh viện Nhi đồng I - Thành phố Hồ Chí Minh từ tháng 9/2018 đến tháng 7/2019.

Tiêu chuẩn chợn bệnh nhân: Bệnh nhân s 15 tuổi được chẩn đoán viêm phổi theo tiêu chuẩn của WHO (2013) [3]: Ho xuất tiết đờm. Nhịp thở nhanh. Rút lõm lồng ngực, rút lõm cơ liên sườn nặng: khó thở nặng, tím tái, rối loạn nhịp thở, ngừng thở... Nghe phổi: ran ẩm nhỏ hạt, có thể kèm ran rít, ran ngáy... X-quang tim phổi: đám mờ to nhỏ không đều, rải rác 2 phổi, tập trung vùng rốn phổi cạnh tim 2 bên, có thể tập trung ở 1 thùy hoặc 1 phân thùy phổi.

Bệnh nhân được siêu âm phổi và chụp Xquang cắt lớp vi tính ngực. Thời gian bệnh nhân được siêu âm phổi và chụp X-quang CLVT ngực cách nhau trong khoảng từ $24-48$ giờ.

Kết quả siêu âm và chụp X-quang cắt lớp vi tính ngực phải mô tả đầy đủ các dấu hiệu tổn thương theo mẫu bệnh án nghiên cứu

Tiêu chuẩn loại trừ: Bệnh nhân không được chụp $X$-quang cắt lớp vi tính ngực hoặc được chụp nhưng quá thời gian quy định trong nghiên cứu ( $>48$ giờ kể từ khi siêu ầm phổi). Bệnh nhân được siêu âm và chụp X-quang cắt lớp vi tính ngực nhưng kết quả không mô tả được đầy đủ các dấu hiệu tổn thương theo mẫu bệnh án nghiên cứu.

\subsection{Phương pháp nghiên cứu}

Phương pháp nghiên cứu: nghiên cứu hồi cứu kết hợp tiến cứu (mô tả ca bệnh). Cõ̃ mẫu: chọn cõ mầu thuận tiện.

Phương tiện nghiên cứu: Máy siêu âm hiệu Siemens tại bệnh viện Nhi Đồng 1, sử dụng 2 loại đầu dò: đầu dò cong (convex) tần số từ 3,5-5 MHz và đầu dò thẳng (linear) tần số từ 7$12,5 \mathrm{MHz}$, kèm sử dụng Doppler màu nếu cần thiết. Máy chụp cắt lớp vi tính Somatom hiệu Philips 16 lát cắt.

Phương pháp tiến hành: Bệnh nhân được siêu âm phổi, sau đó được chụp X-quang CLVT ngực trong vòng từ $24-48$ giờ kể từ khi siêu âm phổi. Thu thập các thông tin liên quan đến bệnh sử của bệnh nhân trong quá trình điều trị tại bệnh viện và được ghi lại theo mẫu bệnh án chung.

Đọc kết quả siêu âm và chụp X-quang CLVT ngực cho các bệnh nhân theo mẫu bệnh án nghiễn cứu. Kễt luận chẩn đoán xác định cuối cùng về viêm phổi cũng như các biến chứng của viêm phổi (tràn dịch màng phổi, tràn khí màng phổi, viêm phổi hoại tử, áp xe phổi và xẹp phổi) và vị trí của các biển chứng (phổi phải, phổi trái, hai phổi) dựa vào X-quang CLVT ngực.

Phương pháp thu thập số liêu: Hồ sơ chẩn đoán ra viện là viêm phổi có biến chứng từ ngày bệnh nhân bị bệnh đến ngày bệnh nhân được siểu âm phổi và chụp X-quang CLVT ngực. Thu thập các biến lâm sàng: Dựa vào hồ sơ bệnh án để thu thập các thông tin về tuổi, giới, tình trạng cân nặng, chiều cao của các bệnh nhi. Các triệu chứng lâm sàng được thu thập dựa vào hồ sơ bệnh án theo bệnh án mẫu. Thu thập các biến trên X-quang CLVT: Các dấu hiệu tổn thương của các biến trên X-quang CLVT ngực được thu thập dựa vào kết quả đọc phim Xquang CLVT ngực của các bác sĩ chuyên khoa có kinh nghiệm theo mẫu bệnh án nghiên cứu. Thu thập các biến trên siêu âm: Các dấu hiệu tổn thương cũng như các biến trên siêu âm phổi được thu thập một cách độc lập với kết quả chụp X-quang CLVT, theo bệnh án mẫu.

Kết quả siêu âm phổi và kết quả đọc phim chụp X-quang CLVT là độc lập với nhau và không biểt kêt quả chẩn đoán của bệnh nhân trước khi làm các xét nghiệm này.

2.3. Xử lý số liệu. Số liệu được nhập bằng excel, xử lý và phẩn tích bằng phương pháp thống kê y học, sử dụng phần mềm SPSS 25.0

\section{KẾT QUẢ NGHIÊN CỨU}

Từ tháng 8 năm 2018 đến tháng 7 năm 2019 có tất cả 53 ca được chọn vào nghiên cứu, tuy nhiên trong quá trình nghiên cứu chúng tôi chì chọn được $43 \mathrm{ca}$, có 10 bệnh nhân bị loại vì không đáp ứng đủ tiêu chuẩn lựa chọn (trong đó có 8 bệnh nhân là không được chụp X-quang CLVT ngực và 02 bệnh nhân X-quang CLVT ngực mộ tả đủ các dấu hiệu tổn thương theo bệnh án mẫu).

Bảng 3.1. Tỷ lệ bệnh nhân viêm phổi và viêm phổi có biến chứng

\begin{tabular}{|c|c|c|c|}
\hline \multicolumn{2}{|c|}{ Chỉ tiêu } & $\begin{array}{c}\text { Số bệnh } \\
\text { nhâ̂n }\end{array}$ & $\begin{array}{l}\text { Tỷ lề } \\
(\%)\end{array}$ \\
\hline \multicolumn{2}{|c|}{ Viêm phổi } & 8 & 18,6 \\
\hline \multicolumn{2}{|c|}{ Viêm phối có biến chứng } & 35 & 81,4 \\
\hline \multicolumn{2}{|l|}{ Công } & 43 & 100 \\
\hline \multirow{2}{*}{$\begin{array}{c}\text { Vị trí biến chứng } \\
(\mathrm{n}=35)\end{array}$} & phổi phải & 30 & 85,7 \\
\hline & phối trái & 25 & 71,4 \\
\hline \multirow{2}{*}{$\begin{array}{l}\text { Số lượng biến } \\
\text { chứng }(n=35)\end{array}$} & 1 & 17 & 48,6 \\
\hline & $\geq 2$ & 18 & 51,4 \\
\hline
\end{tabular}

Nhận xét: Trong 43 bệnh nhân được chẩn 
đoán VP, thì bệnh nhân bị VPCBC là hay gặp, với $35 / 43$ trường hợp chiếm tỷ lệ $81,6 \%$. Và trong 35 bệnh nhân được chẩn đoán VPCBC thì tỷ lệ bệnh nhân bị biến chứng ở phổi phải là cao hơn so với ở phổi trái. Tỷ lệ bệnh nhân bị VPCBC có từ 2 biến chứng trở lên chiếm tỷ lệ khá cao $51,4 \%$, có $17 / 18$ trường hợp chỉ có 1 biến chứng, chiếm tỷ lệ $48,6 \%$.

Bảng 3.2. Các dấu hiệu tổn thương viêm phổi trên siêu âm

\begin{tabular}{|c|c|c|}
\hline $\begin{array}{c}\text { Dấu hiệu } \\
\text { tổn thương }\end{array}$ & $\begin{array}{c}\text { Số bệnh } \\
\text { nhân }(\mathbf{n}=\mathbf{3 5})\end{array}$ & $\begin{array}{c}\text { Tỷ lệ } \\
\text { \% }\end{array}$ \\
\hline Dấu hiệu đông đặc & 33 & 94,3 \\
\hline Đường B & 7 & 20,0 \\
\hline $\begin{array}{c}\text { Mất dấu hiệu trượt } \\
\text { màng phổi }\end{array}$ & 10 & 28,6 \\
\hline
\end{tabular}

Nhận xét: Dấu hiệu tổn thương viêm phổi hay gặp trên hình ảnh siêu âm là dấu hiệu đông đặc với tỷ lệ là $94,3 \%$. Đây cũng là dấu hiệu tổn thương điển hình của viêm phổi. Các dấu hiệu của tổn thương phổi kẽ với hình ảnh đường $B$ và mất dấu hiệu trượt màng phổi trên siêu âm phổi chiếm tỷ lệ tương ứng lần lượt là $20,0 \%$ và $28,6 \%$.

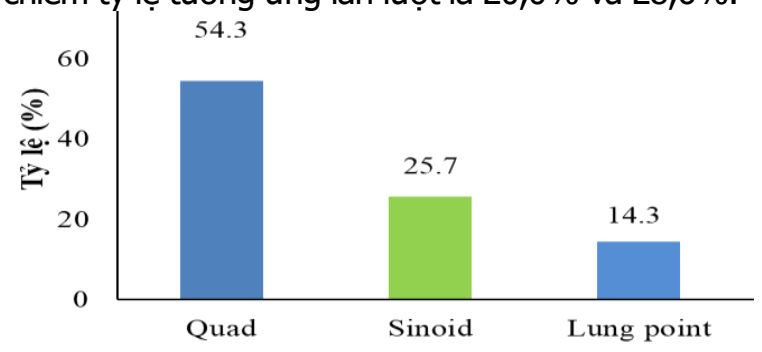

Dấu hiệu

Biểu đồ 3.1. Tỷ lệ các dấu hiệu tổn thương của biến chứng viêm phổi

Nhân xét: Trong tổng số 35 bệnh nhân bi VPCBC, thì dấu hiệu tổn thương biến chứng của viêm phổi thường gặp nhất trên siêu âm là dấu hiệu quad với tỷ lệ là $54,3 \%$. Đây cũng là dấu hiệu tổn thương điển hình của tràn dịch màng phổi. Một dấu hiệu khác của tràn dịch màng phổi quan sát được trên siêu âm là dấu hiệu sinusoid, chiếm tỷ lệ $25,7 \%$. Trong khi đó, chỉ có $14,3 \%$ bệnh nhân bị VPCBC có dấu hiệu lung point trên siêu âm phổi. Dấu hiệu này kết hợp với hình ảnh mất dấu hiệu trượt màng phổi trên siêu âm là triệu chứng điển hình của tràn khí màng phổi.

Bảng 3.3. Tính chât và đặc điểm dịch trên siêu âm

\begin{tabular}{|l|c|c|c|}
\hline \multicolumn{2}{|c|}{$\begin{array}{c}\text { Tính chất và đắc điểm } \\
\text { dịch trên siêu âm }\end{array}$} & $\begin{array}{c}\text { Số bệ̂nh } \\
\text { nhấn } \\
\text { (n=20) }\end{array}$ & $\begin{array}{c}\text { Tỷ lệ } \\
\text { \% }\end{array}$ \\
\hline Tính & Thuân nhất & 12 & 60 \\
\cline { 2 - 4 } chất & Không thuần nhất & 8 & 40 \\
\hline
\end{tabular}

\begin{tabular}{|c|c|c|c|}
\hline \multirow{2}{*}{ Fibrin } & Có & 13 & 65 \\
\cline { 2 - 4 } & Không & 7 & 35 \\
\hline
\end{tabular}

Nhận xét: Trong 20 bệnh nhân viêm phổi được chẩn đoán có biến chứng tràn dịch màng phổi trên siêu âm, thì tính chất của dịch trên hình ảnh siêu âm hay gặp là dịch thuần nhất, chiếm tỷ lệ $60 \%$ và chủ yếu là dịch có fibrin $65 \%$.

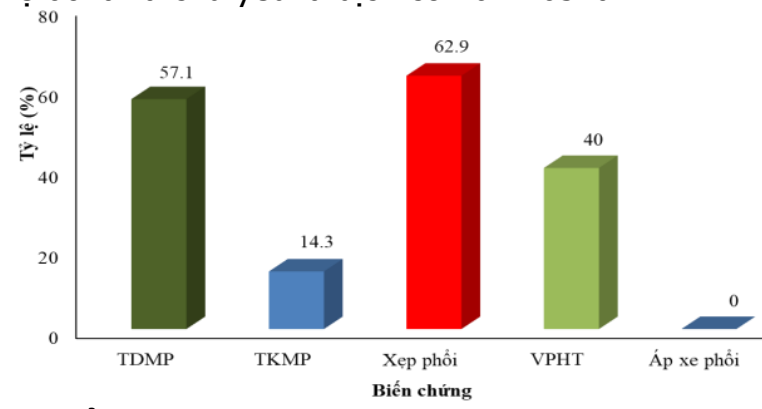

\section{Biêu đồ 3.2. Tỷ lệ các loại biến chứng của viêm phổi trên siêu âm}

Nhân xét: Xẹp phổi, tràn dịch màng phổi, VPHT là các biến chứng hay gặp nhất ở bệnh nhân bị viêm phổi, với tỷ lệ lần lượt là $62,9 \%$, $57,1 \%$ và $40 \%$. Trong khi đó, chỉ có $11,4 \%$ bệnh nhân có biến chứng tràn khí màng phổi và khổng có bệnh nhân nào bị viêm phổi có biến chứng áp xe phổi được phát hiện trên siêu âm phổi.

\section{BÀN LUÂ̂N}

4.1. Các dấu hiệu tổn thương của viêm phổi trên siêu âm

a. Đông đặc phổi. Kết quả nghiên cứu cho thấy dấu hiệu đông đặc phổi là tổn thương hay gặp nhất ở bệnh nhân viêm phổi có biến chứng với tỷ lệ là $94,3 \%$. Đây là tổn thương viêm phổi điển hình, thường thấy trên siêu âm. Kết quả này tương tự kết quả nghiên cứu của các tác giả Lê Cẩm Thạch (2015) [14], đông đặc phổi là dấu hiệu điển hình của viêm phổi, với tỷ lệ $95,3 \%$ và tác giả Kurian (2009) thì dấu hiệu đông đặc phổi cũng được ghi nhận trên siều âm là 18/19 trường hợp chiếm tỷ lệ 94,7\% [2].

Như vậy, kết quả nghiên của chúng tôi là cao hơn so với một số nghiên cứu của các tác giả khác về tỷ lệ của các dấu hiệu tổn thương. Điêu này có thể do trong nghiên cứu của chúng tôi đối tượng bệnh nhân nghiên cứu là các bệnh nhân nhi nhỏ tuổi (từ sơ sinh đến dưới 15 tuổi) và bị viêm phổi có biến chứng. Trong khi các tác giả trên thì nghiên cứu trên các đối tượng là bệnh nhân bị viêm phổi hoặc nghi ngờ viêm phổi, và có tác giả nghiên cứu trên đối tượng nghiên cứu là lớn hơn (dưới 18 tuổi). Ở trẻ nhỏ tổ chức phổi chưa hoàn toàn biệt hoá, ít tổ chức đàn hồi, nhiều mạch máu và bạch huyết nên dễ 
gây xẹp phổi. Mặt khác khi có 1 tổn thương ở phổi dể gây ra rổi loạn tuần hoàn phổi, rối loạn quá trình ngoại hô hấp cũng như quá trình trao đổi khí ở phổi. Tuy nhiên, kết quả nghiên cứu của chúng tôi và của các tác giả trên đều cho thây dấu hiệu đông đặc phổi là dấu hiệu tổn thương chủ yếu thường gặp ở bệnh nhân bị viêm phổi có biến chứng.

b. Hội chứng mô kẽ. Đường $B$ là dấu hiệu đăc trưng của tổn thương mô kẽ ở bệnh nhân bị viêm phổi. Kết quả nghiên cứu ở bảng 3.4 cũng cho thấy tỷ lệ bệnh nhân có dấu hiệu đường $B$ và mất dấu hiệu trượt màng phổi tương ứng lần lượt là $20 \%$ và 28,6 .

Như vậy, kết quả nghên cứu của chúng tôi cho thấy tỷ lệ tổn thương phổi kẽ của chúng tôi cao hơn các nghiên cứu trên. Lý giải cho sự khác biệt trên có thể do trong nghiên cứu của chúng tôi có tỷ lệ gặp viêm phổi hai bên rất cao với $57,6 \%$, trong khi ở các nghiên cứu trên thì tỷ lệ tổn thương ở cả 2 phổi là thấp hơn nhiều (nghiên cứu của tác giả Çağla tỷ lệ bệnh nhân bị tổn thương ở 2 phổi là 26,9\%, Cortellaro tỷ lề bệnh nhân bị tổn thương ở 2 phổi chỉ có $8 \%$ ). Điều này cho thãy tổn thương phổi trong nghiên của chúng tôi có tính chất lan tỏa hơn so với các nghiên cứu trên, tổn thương lan tới khoảng kẽ sẽ cao hơn, nên khả năng bắt gặp đường $B$ trên siêu âm phổi cao hơn so với các nghiên cứu trên.

\subsection{Các dấu hiệu tổn thương của biến} chứng viêm phổi trền siêu âm

a. Tràn dịch màng phổi. Kết quả nghiên cứu ở Biểu đồ 3.2 cho thấy tỷ lệ bệnh nhân có dấu hiệu quad và dấu hiệu sinusoid trên hình ảnh siêu âm lần lượt là $54,3 \%$ và $25,7 \%$.

b. Tràn khí màng phổi. Trong nghiên cứu của chúng tôi cho thây chỉ có $14,3 \%$ bệnh nhân bị VPCBC có dấu hiệu lung point trên siêu âm phổi và $26,1 \%$ bệnh nhân bị mất dấu hiệu trượt màng phổi. Đồng thời kết quả nghiên cứu của chúng tôi đều cho thây $100 \%$ bệnh nhân được chẩn đoán TKMP trên siêu âm đều có dấu hiệu lung point và mất dấu hiệu trượt màng phổi trền siêu âm.

Nhìn chung, các dấu hiệu của biến chứng viêm phổi trong nghiên cứu của chúng tôi là cao hơn so với các nghiên cứu trên. Điều này có thể là do đối tượng nghiên cứu của chúng tôi là những bệnh nhân viêm phổi có biến chứng tại phổi hoặc ở màng phổi. Trong khi đó, đối tượng nghiên cứu của hầu hết các tác giả nói trên chỉ là những bệnh nhân bị viêm phổi (bệnh nhân có thể có biến chứng, hoặc không có biến chứng của viêm phổi). Do đó, tỷ lệ các dấu hiệu tổn thương biến chứng của viêm phổi nói trên trong nghiên cứu của chúng tôi là cao hơn.

4.3. Biến chứng của viêm phổi trên siêu âm

a. Tràn dịch màng phổi. Tràn dịch màng phổi (TDMP) là hiện tượng xuất hiện dịch nhiều hơn mức sinh lý bình thường trong khoang màng phổi, do nhiều nguyên nhân gây nên và làm biến đổi trên lâm sàng và xét nghiệm. Bình thường lượng dịch trong khoang màng phổi chỉ có khoảng $10-15 \mathrm{ml}$. Đây là một trong các biến chứng hay gặp ở bệnh nhi bị viêm phổi. Kết quả nghiên cứu ở biểu đồ 3.3. cho thấy tỷ lệ bệnh nhân viêm phổi có biến chứng TDMP là $57,1 \%$. Kết quả này là tương tự kết quả nghiên cứu của tác giả Reissig (2012), tỷ lệ tràn dịch màng phổi ở bệnh nhân bị viêm phổi là $54,4 \%$.

b. Tràn khí màng phổi. Tràn khí màng phổi là tình trạng khí tích tụ trong khoang màng phổi dẫn đến xẹp phổi thu động và ảnh hưởng đến hô hấp. Kết quả nghiển cứu cho thấy tỷ lệ bệnh nhân bị viêm phổi có biến chứng TKMP là $14,3 \%$. Kết quả này là cao hơn so với kết quả nghiên cứu của tác giả Krenke (2015), tỷ lệ tràn khí màng phổi ở bệnh nhân bị viêm phổi hoại tử là $6,25 \%$.

c. Xẹp phổi. Xep phổi là tình trang chèn ép hoặc tắc nghẽn phổi dẫn đến giảm hay mất khả năng trao đổi khí. Nó có thể ảnh hưởng đến một phần hoặc toàn bộ phổi. Đây là một loại biển chứng thường thấy ở bệnh nhi bị viêm phổi. Kết quả nghiên cứu ở biểu đồ 3.3. cho thấy tỷ lệ bệnh nhân viêm phổi có biến chứng xẹp phổi là $62,9 \%$. Kết quả này là cao hơn so với kểt quả nghiên cứu của các tác giả Fishburn (1990), nghiên cứu trên 46 bệnh nhân bị viêm phổi cho thấy tỷ lệ bệnh nhân có biến chứng xẹp phổi là $50 \%$.

d. Viêm phổi hoại tử. Viêm phổi hoại tử (VPHT) là một thể nặng của bênh lý phổi với sự hình thành của các hang nhỏ, áp-xe nhỏ $(<2 \mathrm{~cm})$ trong nhu mô phổi, thường không kèm theo tổn thương màng phổi đáng kể. Trong nghiên cứu của chúng tôi tỷ lệ bệnh nhân bị VPHT chiếm tỷ lệ $40 \%$.

Như vậy, các kết quả nghiên cứu trên cho thấy tràn dịch màng phổi, viêm phổi hoại tử và xẹp phổi là những biến chứng hay gặp ở bệnh nhân viêm phổi. Điều này phù hợp với kết quả nghiên cứu của nhiều tác giả khác trên thế giới.

Bên cạnh đó, các kết quả nghiên cứu trên còn cho thấy tỷ lệ bệnh nhân bị viêm phổi có biến chứng có xu hướng ngày càng tăng.

Mặt khác, kết quả nghiên của chúng tôi là cao hơn so với một số nghiên cứu của các tác giả khác về tỷ lệ của các biến chứng của viêm 
phổi. Điều này có thể do trong nghiên cứu của chúng tôi đối tượng bệnh nhân nghiên cứu là các bệnh nhân nhi nhỏ tuổi (từ sơ sinh đến dưới 15 tuổi) và bị viêm phổi có biến chứng (được chẩn đoán bằng $\mathrm{X}$-quang $\mathrm{CLVT}$ ngực). Trong khi các tác giả trên thì nghiên cứu trên các đối tượng là bệnh nhân bị viêm phổi hoặc nghi ngờ viêm phổi, và có tác giả nghiên cứu trên đối tượng nghiên cứu là là những bệnh nhân lớn tuổi hơn (dưới 18 tuổi). Ở trẻ nhỏ tổ chức phổi chưa hoàn toàn biệt hoá, ít tổ chức đàn hồi, nhiều mach máu và bạch huyết nên dễ gây xẹp phổi (Điều này có thể giải thích tại sao xẹp phổi là biến chứng hay gặp nhất trong các loại biến chứng của viêm phối với tỷ lệ là 62,9\%). Bên cạnh đó, khi có 1 tổn thương ở phổi dễ gây ra rối loạn tuần hoàn phổi, rối loạn quá trình ngoại hô hấp cũng như quá trình trao đổi khí ở phổi. Do những đặc điểm giải phẫu sinh lí bộ phận hô hấp ở trẻ em, nhất là trẻ nhỏ dễ mắc bệnh đường hô hấp, đặc biệt là viêm phổi [6], [7]. Sự khác biệt này có thể dẫn tới sự khác biệt về tỳ lệ của các biến chứng của chúng tôi so với của các tác giả trên.

\section{KẾT LUÂ̂N}

Các dấu hiệu tổn thương viêm phổi cơ bản thường gặp theo thứ tự là dấu hiệu đông đặc, mất dấu hiệu trượt màng phổi và đường $B$ với tỷ lệ lần lượt là 94,3\%, 28,6\% và 20,0\%.
Các dấu hiệu tổn thương của biến chứng viêm phổi hay gặp theo thứ tự là dấu hiệu quad, dấu hiệu signoid và dấu hiệu lung point với tỷ lệ lần lượt là $53,4 \%, 25,7 \%$ và $14,3 \%$.

Xẹp phổi, tràn dịch màng phổi, viêm phổi hoại tử và tràn khí màng phổi là các biến chứng hay gặp của viêm phổi, với tỷ lệ tương ứng là $62,9 \%, 57,1 \%, 40 \%$ và $14,3 \%$.

\section{TÀI LIẸU THAM KHẢO}

1. Brenner DJ, Hall EJJNEJoM (2007), Computed tomography -an increasing source of radiation exposure, 357(22), pp. 2277-2284.

2. Kurian J, Levin $\mathrm{TL}$, Han $B K$, Taragin $B H_{\text {, }}$ Weinstein S (2009), Comparison of ultrasound and CT in the evaluation of pneumonia complicated by parapneumonic effusion in children, AJR Am J Roentgenol, 193(6), pp. 1648-54.

3. Organization WH, Pocket book of hospital care for children: guidelines for the management of common childhood illnesses. 2013: World Health Organization.

4. Rudan I, Boschi-Pinto C, Biloglav Z, Mulholland K, Campbell H (2008), Epidemiology and etiology of childhood pneumonia, Bull World Health Organ, 86(5), pp. 408-16.

5. Xia $Y$, Ying $Y$, Wang $S$, Li W, Shen HJJotd (2016), Effectiveness of lung ultrasonography for diagnosis of pneumonia in adults: a systematic review and meta-analysis, 8(10), pp. 2822.

6. Khánh NG, Bai giảng Nhi khoa tập 1. 2013, NXB Y học: Trường Đại học Y Hà Nội. tr. 390-401.

7. Kim HT, Bài giảng Nhi khoa. 2013, NXB Y hoc Đại học Y dược Thành phố Hồ Chí Minh. tr. 267 -295.

\title{
THAY ĐỔI NỒNG Độ CYTOKINE HUYẾT THANH Ở BÊ̂NH NHÂN VIÊM PHỔI CộNG ĐỒNG DO VI KHUẨN
}

\author{
Lê Thị Diệu Hiền**, Mai Xuân Khẩn**, Tạ Bá Thắng*
}

\section{TÓM TẮT}

Đặt vấn đề: Viêm phổi cộng đồng (VPCĐ) là một trong những bệnh nhiễm trùng đường hô hấp dưới có tỷ lề mắc và tỷ lệ tử vong cao. Nông độ cytokine huyết thanh có vai trò quan trọng trong đánh giá mức độ nặng và tiên lượng bệnh nhân viêm phổi. Mục tiêu: Đánh giá sự thay đổi nồng đô cytokine huyết thanh ở bệnh nhân viêm phổi cộng đồng do vi khuẩn. Đối tướng và phương pháp: Nghiên cứu trên 78 bệnh nhân VPCĐ điều trị tại Bệnh viện Hữu Nghị Việt Tiêp Hải phòng từ tháng 1 năm 2016 đển tháng 12 năm 2019. Các bệnh nhần được cấy khuẩn đờm trước

*Học viện Quân Y

**Đai hoc Y Dước Hải phòng

Chịu trách nhiệm chính: Lê Thị Diệu Hiền

Email: hienbmn612@yahoo.com

Ngày nhận bài: 2.3.2021

Ngày phản biên khoa hoc: 23.4 .2021

Ngày duyệt bài: 4.5.2021 khi dùng kháng sinh. Kết quả và kết luận: Kết quả cấy khuẩn đờm mọc vi khuẩn Gram âm là 62 BN chiếm $79,49 \%$ và Gram dương là 16 BN chiếm $20,51 \%$. Giá tri trung vi các cytokine của nhóm bênh tại ngày 1 và ngày 7 đều cao hơn nhóm chứng và ở ngày 7 thấp hơn ngày 1 . Với 5 vi khuẩn thường gặp cho thây TNF-a, IL-6 và IL-10 tăng chiếm đa số. Nhóm vi khuẩn Gram dương có giá trị IL-6 và IL-10 cao hơn nhóm Gram âm nhưng giá trị TNF-a lại thấp hơn.

Tư khóa: Viêm phối mắc phải cộng đông; Đặc điểm vi khuẩn; Cytokine

\section{SUMMARY}

\section{CHANGES IN SERUM CYTOKINE LEVELS IN PATIENTS WITH COMMUNITY-ACQUIRED BACTERIAL PNEUMONIA}

Background: Community-acquired pneumonia (CAP) is one of the lower respiratory tract infections with high morbidity and mortality. Level of serum cytokine plays an important role in assessing the severity and prognosis of patients with pneumonia. 